\title{
Polymerase chain reaction and nested-PCR approaches for detecting Cryptosporidium in water catchments of water treatment plants in Curitiba, State of Paraná, Brazil
}

\author{
Silvia Cristina Osaki ${ }^{[1],[2],}$ Vanete Thomaz Socco ${ }^{[1],[3]}$, Adriana Oliveira Costa ${ }^{[4]}$, \\ Márcia Benedita Oliveira-Silva ${ }^{[5]}$, Juliana Tracz Pereira ${ }^{[6]}$ \\ and Antônio Eduardo Procópio ${ }^{[1]^{+}}$
}

[1]. Programa de Pós-Graduação em Processos Biotecnológicos e Biotecnologia, Centro Politécnico, Universidade Federal do Paraná, Curitiba, PR. [2]. Curso de Medicina Veterinária, Universidade Federal do Paraná, Palotina, PR. [3]. Programa de Pós Graduação em Gestão Ambiental, Universidade Positivo, Curitiba, PR. [4]. Departamento de Análises Clínicas e Toxicológicas, Faculdade de Farmácia, Universidade Federal de Minas Gerais, Belo Horizonte, MG. [5]. Disciplina de Parasitologia, Departamento de Ciências Biológicas, Universidade Federal do Triângulo Mineiro, Uberaba, MG. [6]. Departamento de Patologia Básica, Centro Politécnico, Universidade Federal do Paraná, Curitiba, PR, Curitiba, PR. † In memoriam.

\begin{abstract}
Introduction: Cryptosporidium is an important protozoan cause of waterborne disease worldwide of concern to public health authorities. To prevent outbreaks of cryptosporidiosis, the monitoring of this parasite in drinking water is necessary. In the present work, the polymerase chain reaction (PCR) and nested-PCR techniques were used to detect Cryptosporidium in raw water from catchment points of four water treatment plants (WTP) in Curitiba, Paraná, Brazil. Methods: First, DNA extraction techniques were tested in samples containing decreasing amount of oocysts in reagent water, and PCR and nested-PCR with specific primers for 18SSU rDNA of Cryptosporidium were conducted to determine their sensitivity. In reagent water, a commercial extraction kit provided the best analytical sensitivity, and PCR and nested-PCR allowed the detection of five and two oocysts, respectively, with the primers XIAOR/XIAOF and XIAO1F/XIAO2R. Results: In the spiking experiments, only the PCR with the primers AWA995F/AWA1206R was successful at detecting concentrations of 0.1 oocysts $/ \mathrm{mL}$. Two catchments samples of raw water and/or water sludge from four WTPs were contaminated with Cryptosporidium. Conclusions: The application of the techniques to monitor Cryptosporidium in water and detect contamination in water catchments of WTPs in Curitiba are discussed in the present work.
\end{abstract}

Keywords: Cryptosporidium. Polymerase chain reaction. Nested-PCR. DNA extraction technique. Water.

\section{INTRODUCTION}

The intestinal coccidia Cryptosporidium is considered one of the most important protozoan causes of waterborne diarrhea worldwide ${ }^{1}$. Infection in humans can cause aqueous diarrhea, abdominal cramps, nausea, headaches, and anorexia. Cryptosporidiosis is particularly severe in immune-depressed individuals such as HIV-positive patients, patients who are receiving chemotherapy or organ transplants, and children².

Cryptosporidium parvum is the most commonly encountered ${ }^{3}$ species of Cryptosporidium that parasitizes humans and domestic or wild animals. Infection takes place when hosts ingest the infective stages (oocysts); these oocysts can survive

\footnotetext{
Address to: Dr ${ }^{\mathrm{a}}$ Silvia Cristina Osaki. Curso de Medicina Veterinária/UFPR. Rua Pioneiro 2153, Setor Palotina, 85950-000 Palotina, PR, Brasil.

Phone: 5544 3211-8562

e-mail: sil_osaki@ufpr.br; silvia_cristinao@yahoo.com.br

Received 9 March 2013

Accepted 12 June 2013
}

for 180 days in water and for up to one year at $4^{\circ} \mathrm{C}^{4}$. Newborn calves are particularly susceptible to infection and may excrete approximately 30 billion or more oocysts in one or two weeks 5 .

The reduced size $(2-4 \mu \mathrm{m})$ and resistance of oocysts facilitate their passage through the mechanical and chemical barriers used in conventional water treatment plants ${ }^{6,7}$. Such characteristics, combined with the low infective dose, contribute to the occurrence of waterborne outbreaks in many parts of the world ${ }^{8}$.

Cryptosporidium is difficult to detect with routinely used techniques, particularly due to its low concentration in water 9 . Method 1623 of the US Environmental Protection Agency ${ }^{10}$ was developed for monitoring Cryptosporidium in water and consists of stages including filtration, concentration, immunomagnetic separation (IMS), and detection with DAPI and fluorescent antibodies. The complexity and high costs of this method preclude its application in developing countries such as Brazil.

In Brazil, Regulation 2914 of December 12 $2^{\text {th }}$, 2011, states that when the arithmetic mean concentration of Cryptosporidium spp. is greater than or equal to 3.0 oocysts/L of water in catchment areas, rapid filtration with effluent turbidity values less than or equal to $0.3 \mathrm{UT}$ of $95 \%$ of monthly samples is recommended ${ }^{11}$. However, few local laboratories are able to 
apply any methodologies to detect Cryptosporidium and Giardia. Therefore, it is necessary to develop other methodologies that detect Cryptosporidium in water with sensitivity and specificity at more accessible costs for the country.

An alternative approach is the polymerase chain reaction (PCR), which provides thousands of amplifications of specific sequences of deoxyribonucleic acid (DNA). Because of this ability, PCR is a promising technique for use in samples in which the organisms of interest exist in small quantities, as is the case of Cryptosporidium in water. Here, we utilize molecular techniques (PCR and nPCR) to detect Cryptosporidium in watershed catchments and sludge from four water treatment plants in Paraná State in southern Brazil.

\section{METHODS}

\section{Preparation of parasite samples}

The Cryptosporidium parvum oocysts used in the study were obtained from experimental infection in a newborn calf and purified with the sucrose discontinuous gradient technique ${ }^{12}$. The parasites were quantified in a Neubauer counting chamber and stored under refrigeration $\left(4^{\circ} \mathrm{C}\right)$ for up to one month. Sets of separate microtubes $(1.5 \mathrm{~mL})$ containing $500 \mu \mathrm{L}$ of ultra-pure water were inoculated with $10^{5}, 10^{4}, 10^{3}, 10^{2}, 10,5,4,3,2$, and 1 oocyst, separately. Lower quantities of oocysts (10 to 1 ) were prepared by microscopic examination of 3- to $5-\mu \mathrm{L}$ drops of a diluted suspension on microscope slides. After detecting the desired quantities, the drop was aspirated and transferred to the appropriate microtube.

\section{DNA extraction}

To determine the best technique for DNA extraction, four protocols were tested. In the first protocol, oocysts samples were subjected to three freeze/thaw cycles $(5 \mathrm{~min}$ in liquid nitrogen and five minutes at $37^{\circ} \mathrm{C}$ ) in $500 \mu \mathrm{L}$ of lysis buffer TEN (10mM Tris HCl, 10mM EDTA, $150 \mathrm{mM} \mathrm{NaCl}, \mathrm{pH} 8.0$ ). The mixture was incubated at $37^{\circ} \mathrm{C}$ for $60 \mathrm{~min}$ with $5 \mu \mathrm{L}$ of fresh lysozyme solution $(20 \mathrm{mg} / \mathrm{mL})$. Sodium dodecyl sulfate (SDS) at a final concentration of $0.5 \%$ was added. Proteinase $\mathrm{K}$ treatment, RNAse treatment, and the subsequent steps of DNA extraction using phenol-chloroform-isoamyl alcohol and sodium acetate/ethanol precipitation were performed as described by Sambrook ${ }^{13}$. In the second protocol, oocyst samples were suspended in $500 \mu \mathrm{L}$ of lysis buffer $(10 \mathrm{mM}$ Tris- $\mathrm{HCl} \mathrm{pH}$ 8.0, 5mM EDTA pH 8.0, $1 \%$ SDS, $0.5 \mathrm{mM} \beta$-mercaptoethanol). Enzymatic treatment with lysozyme, proteinase K and RNAse and the subsequent steps of DNA extraction were performed as described in the first protocol. In the third protocol, oocyst samples were subjected to a salting-out DNA extraction method ${ }^{14}$ with modifications. Briefly, samples were subjected to 15 freeze/thaw cycles $\left(5 \mathrm{~min}\right.$ in dry ice and $2 \mathrm{~min}$ at $\left.56^{\circ} \mathrm{C}\right)$ in $80 \mu \mathrm{L}$ of TE $5 \mathrm{X}$ ( $50 \mathrm{mM}$ Tris $\mathrm{HCl} \mathrm{pH} 8.0,50 \mathrm{mM}$ EDTA). The volume was filled to $400 \mu \mathrm{L}$ with distilled water, $0.75 \mathrm{mg} / \mathrm{mL}$ proteinase $\mathrm{K}$ and $1 \% \mathrm{SDS}$. After incubation at $55^{\circ} \mathrm{C}$ for $2-3 \mathrm{~h}$, the samples were cooled at room temperature. Deproteinization with $6 \mathrm{M}$ $\mathrm{NaCl}$ and DNA precipitation with ethanol were performed as previously described ${ }^{14}$. In the fourth protocol, oocyst samples were subjected to 15 cycles of freezing in liquid nitrogen for five minutes and thawing at $37^{\circ} \mathrm{C}$ for $2 \mathrm{~min}$ in $1,000 \mu \mathrm{L}$ of lysis buffer provided by the ChargeSwitch ${ }^{\circledR}$ gDNA Mini Tissue Kit. The subsequent steps of the extraction were performed according to the manufacturer's instructions.

\section{PCR and nested-PCR}

Two PCR reactions were tested using two sets of primers. The first set, AWA995F/AWA1206R (5'TAG AGA TTG GGG TTG TTC CT/ 5'CTC CAC CAA CTA AGA ACG GCC), amplifies the hyper-variable region of the gene encoding the 18 SSU rDNA of the genus Cryptosporidium ${ }^{15,16}$. Henceforth, these primers will be designated AWA. The second set, XIAOF XIAOR (5'TTC TAG AGC TAA TAC ATG CG/5'CCC ATT TCC TTC GAA ACA GGA), were used to amplify the hypervariable region of the gene encoding the 18SSU rRNA of the genus Cryptosporidium. These were used for the first initial PCR; the subsequent nested PCR was performed using primers XIAO1F/XIAO2R (5'AAG GAG TAA GGA ACA ACC TCC A/ 5'GGA AGG TTG TAT TTA TTA GAT AAA G) ${ }^{17}$. These primers will henceforth be designated XIAO.

All reactions were conducted in a final volume of $25 \mu \mathrm{L}$, containing $200 \mu \mathrm{M}$ of each dNTP and $5 \mu \mathrm{L}$ of DNA template. The other compounds and conditions of the reaction are described in the Table 1. The products were separated by electrophoresis in a 1.6\% agarose gel and stained with ethidium bromide.

\section{Spiked raw water assays}

Coagulation/Flocculation assays: To evaluate whether PCR could detect Cryptosporidium in raw water, the parasite concentration was determined by coagulation assays performed using Jartest ${ }^{\circledR}$ equipment. Raw water was collected in a 20-L container at the catchment area of the Iguaçu Water Treatment Plant (WTP) in the metropolitan region of Curitiba, Paraná, Brazil. The temperature, $\mathrm{pH}$, color, and turbidity of the samples were recorded. The raw water was immediately taken to the laboratory, homogenized, and 2-L samples were transferred to the jars. The jars were spiked with oocysts at a final concentration of $0.1,1,10$ or 100 oocysts $/ \mathrm{mL}$ in triplicate. After spiking the oocysts, a $1 \%$ aluminum sulfate solution was added to each jar to a final concentration of $27.5 \mathrm{ppm}, 29.5 \mathrm{ppm}$ or $31.5 \mathrm{ppm}$. These concentrations were chosen based on the amount of coagulant used by the WTP $(29.5 \mathrm{ppm})$ on the day of collection; a variation of $2 \mathrm{ppm}$ above and below these concentrations were also adopted to test whether such variations could influence the PCR results.

A negative control (without spiked oocysts) was included in the assays. The following cycles were adopted: $20 \mathrm{sec}$ for coagulation at $100 \mathrm{rpm} ; 20 \mathrm{~min}$ for flocculation and $20 \mathrm{~min}$ for decantation at $45 \mathrm{rpm}$. Fifty milliliters of decanted water were collected, and the color, turbidity, and $\mathrm{pH}$ of the samples were recorded.

Processing of flocculated material: Approximately $900 \mathrm{~mL}$ of decanted water were discarded, and the remaining $900 \mathrm{~mL}$ of flocculated material were decanted for two more hours in a 
TABLE 1 - Compounds and conditions used for PCR and nested-PCR to detect Cryptosporidium oocysts, performed in a final volume of $25 \mu \mathrm{L}$ with $200 \mu \mathrm{M}$ of dNTPs and $5 \mathrm{~mL}$ of DNA template.

\begin{tabular}{|c|c|c|c|c|c|}
\hline Primers & $\begin{array}{c}\mathrm{MgCl}_{2} \\
(\mathrm{mM})\end{array}$ & $\begin{array}{c}\text { Amount of each } \\
\text { primer }(\mu \mathrm{M})\end{array}$ & $\begin{array}{c}\text { Taq DNA } \\
\text { polymerase }^{\mathrm{a}}(\mathrm{U})\end{array}$ & Cycling & $\mathrm{Tm}$ \\
\hline AWA995F & 2 & 0.8 & 1.25 & $95^{\circ} \mathrm{C}-7 \mathrm{~min} ; 40 \mathrm{X}\left(94^{\circ} \mathrm{C}-1 \mathrm{~min} / 54^{\circ} \mathrm{C}-\right.$ & $60^{\circ} \mathrm{C}$ \\
\hline AWA1206R & & & & $\left.1 \mathrm{~min} / 72^{\circ} \mathrm{C}-3 \mathrm{~min}\right) ; 72^{\circ} \mathrm{C}-7 \mathrm{~min}$. & $66^{\circ} \mathrm{C}$ \\
\hline XIAOF & 3 & 0.8 & 1.25 & $94^{\circ} \mathrm{C}-3 \min , 35 \mathrm{X}\left(94^{\circ} \mathrm{C}-45 \mathrm{sec} / 55^{\circ} \mathrm{C}-\right.$ & $56^{\circ} \mathrm{C}$ \\
\hline XIAOR & & & & $\left.1 \mathrm{~min} / 72^{\circ} \mathrm{C}-1 \mathrm{~min}\right) ; 72^{\circ} \mathrm{C}-7 \mathrm{~min}$ & $63^{\circ} \mathrm{C}$ \\
\hline $\mathrm{XIAO} 2 \mathrm{R}^{\mathrm{b}}$ & & & & $\left.\min / 72^{\circ} \mathrm{C}-1 \mathrm{~min}\right) ; 72^{\circ} \mathrm{C}-7 \mathrm{~min}$. & $54^{\circ} \mathrm{C}$ \\
\hline
\end{tabular}

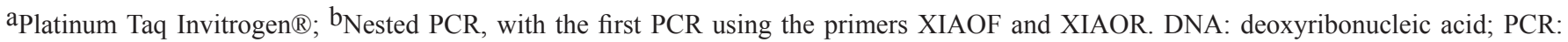
polymerase chain reaction; dNTPs: deoxyribonucleotide triphosphate; $\mathrm{MgCl}_{2}$ : magnesium chloride; Tm: temperature melting.

conical sedimentation chalice. The supernatant was discarded, and $200 \mathrm{~mL}$ of material was concentrated by centrifugation at $300 \mathrm{xg}$ for $10 \mathrm{~min}$. The pellet was suspended in PBST (phosphate buffered saline with $0.01 \%$ Tween) in a final volume of $50 \mathrm{~mL}$. Following a vigorous agitation, the material was submitted to discontinuous gradient using $1.0 \mathrm{M}$ sucrose, as previously described ${ }^{18}$. The particles in the PBST-sucrose interface were collected and washed three times by centrifugation at $450 \mathrm{xg}$ for $10 \mathrm{~min}$. The pellet was subjected to DNA extraction with a ChargeSwitch ${ }^{\circledR}$ gDNA Mini Tissue Kit, and the DNA was used for the PCR reactions.

\section{Detection of Cryptosporidium in the water of catchment areas}

Raw water collection: In December 2008 and January 2009, raw water was obtained at the water-intake point of the Iguaçu, Iraí, Passaúna and Rio Pequeno WTPs, all located in the Metropolitan Region of Curitiba, Paraná, Brazil. Water was harvested in a 20-L container, and the temperature, alkalinity, $\mathrm{pH}$, color, and turbidity of the water were recorded. Three independent collections were performed at each WTP on December 2, 2008, December 16, 2008 and January 12, 2009. The materials were immediately transported to the laboratory.

Coagulation/flocculation assays and flocculated material processing: Homogenized 2-L samples were transferred to the jars and $1 \%$ aluminum sulfate solution was added at the final concentration recommended by the WTPs on the day of collection. Cycles for the coagulation process, procedures for measuring physico-chemical parameters $(\mathrm{pH}$, color and turbidity), and the processing of flocculated material for PCR were performed as described in the previous section (spiked raw water assays).

Water sludge processing: To improve the chances of detecting the parasites in water catchment areas, water sludge samples from the WTPs were also processed for PCR. At the time of raw water collection, one liter of sludge was obtained from the discharge location. Each sample of water sludge was processed using the Yanko method ${ }^{19}$. Briefly, $0.1 \%(\mathrm{v} / \mathrm{v})$ Tween 80 was added to the entire sludge sample $(1 \mathrm{~L})$, which was then homogenized and filtered through a 48-mesh sieve. The filtered mixture was decanted overnight in a 2-L beaker. After discarding the supernatant, the sediment was distributed in conical $50-\mathrm{mL}$ tubes and centrifuged at $1,220 \mathrm{xg}$ for $5 \mathrm{~min}$. Sediments were then suspended in zinc sulfate solution with a density of 1.20 and centrifuged again at $1,220 \mathrm{xg}$ for $5 \mathrm{~min}$. The supernatants from the tubes were accumulated in a beaker, the same volume of distilled water was added, and the mixture was decanted overnight. The supernatant was discarded by aspiration, the sediments were centrifuged at $270 \mathrm{xg}$ for $5 \mathrm{~min}$, and the pellets were accumulated in a single tube. A new centrifugation was performed to eliminate the supernatant, and the pellet was resuspended in $7 \mathrm{~mL}$ of alcohol-acid solution $\left(0.1 \mathrm{~N} \mathrm{H}_{2} \mathrm{SO}_{4}\right.$ in $35 \%$ ethanol) and $2 \mathrm{~mL}$ of ether. After inverting the tube several times, it was centrifuged at $440 \mathrm{xg}$ for $3 \mathrm{~min}$, and the supernatant was discarded. The pellet was resuspended in lysis buffer from a ChargeSwitch ${ }^{\circledR}$ gDNA Mini Tissue Kit, and the DNA was used for PCR reactions.

\section{RESULTS}

The protocols used for DNA extraction that involved phenol-chloroform-isoamyl alcohol and sodium acetate/ ethanol precipitation required a minimum of $10^{3}$ oocysts to produce successful amplification with PCR or nested-PCR. The third method (salting-out) for DNA extraction was able to detect $10^{2}$ oocysts with the AWA primers, but the sensitivity of detection was lower than in the other amplification reactions. An improvement in the sensitivity was obtained when the ChargeSwitch ${ }^{\circledR}$ kit was used, as five oocysts could be detected in a one-step PCR with the XIAO primers and two oocysts could be detected with the nested-PCR (Figure 1).

The samples of water spiked with Cryptosporidium oocysts displayed a significant decrease in turbidity and color after the coagulation/flocculation process was conducted, regardless of the concentration of coagulant used. The flocculated material was then processed for DNA extraction with the kit, which provided a better DNA template based on the previous experiments. The PCR with the AWA primers could detect the parasite in samples spiked with 100 to 0.1 oocyst $/ \mathrm{mL}$ and processed with different concentrations of the coagulant. On 


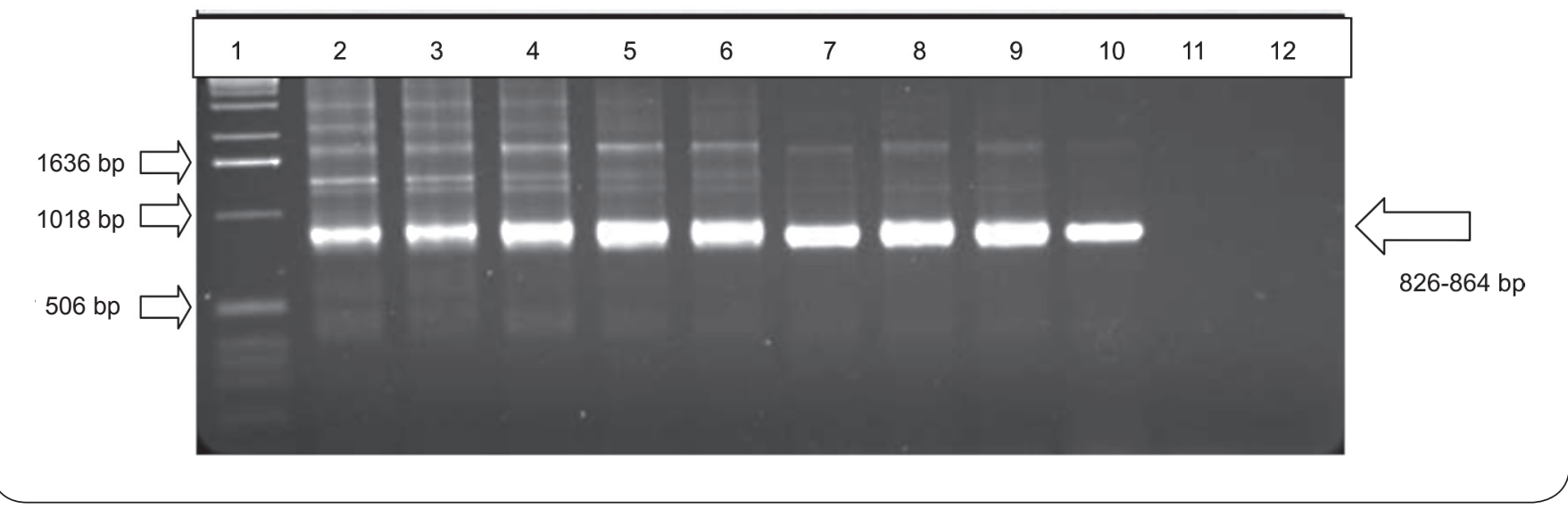

FIGURE 1 - Agarose gel electrophoresis (1.6\%) showing genetic fragment amplification products from Nested-PCR performed with the XIAO primers with different concentrations of Cryptosporidium parvum oocysts; DNA was extracted with a commercial kit ${ }^{\circledR}$. The arrow indicates the expected position of the fragment in the amplification. 1: MW: standard molecular weight; $2: 10^{4}$ oocysts; $3: 10^{3}$ oocysts; 4: 500 oocysts; 5: 100 oocysts; $6: 50$ oocysts; 7: 10 oocysts; 8: 5 oocysts; 9: 4 oocysts; 10: 2 oocysts; 11: 1 oocyst; 12: negative control. bp: base pairs.

the other hand, no signal amplification was obtained with the XIAO primers in either the PCR or the nested-PCR.

Experiments using the Jartest ${ }^{\circledR}$ with samples of surface water from four catchment points in Curitiba, Paraná, Brazil required an aluminum sulfate concentration that varied from
10 to $31 \mathrm{ppm}$. Following the coagulation assays, an improvement in the color and turbidity of the water samples collected at the Iguaçu, Iraí, and Rio Pequeno catchments was observed. Samples from the Passaúna catchment presented minimal decreases or slight increases in turbidity following coagulation (Table 2).

TABLE 2 - Positivity of the PCR in samples of raw water with an initial pH of 6.3, color 100 and turbidity 18NTU, from the Passaúna Water Treatment Plant (Curitiba, Paraná, Brazil), spiked with 0.1 to 100 oocysts/mL of Cryptosporidium.

\begin{tabular}{|c|c|c|c|c|c|c|}
\hline \multirow[b]{2}{*}{$\mathrm{Al}_{2}\left(\mathrm{SO}_{4}\right)_{3} \mathrm{ppm}$} & \multirow[b]{2}{*}{$\begin{array}{l}\text { Contamination } \\
\text { (oocysts/mL) }\end{array}$} & \multirow[b]{2}{*}{$\mathrm{pH}$} & \multicolumn{4}{|c|}{ Physico-chemical parameters of water } \\
\hline & & & $\begin{array}{c}\text { decanted water } \\
\text { color } \\
\end{array}$ & turbidity & $\begin{array}{c}\text { flocculated material } \\
\mathrm{pH} \\
\end{array}$ & $\begin{array}{l}\text { PCR positivity in } \\
\text { flocculated material }\end{array}$ \\
\hline 27.5 & $\mathrm{CN}$ & 6.4 & 15 & 5.22 & 6.5 & - \\
\hline \multirow[t]{3}{*}{27.5} & 0.1 & 6.1 & 15 & 2.51 & 6.3 & + \\
\hline & 10 & 6.5 & 10 & 3.72 & 6.3 & + \\
\hline & 100 & 6.4 & 5 & 1.61 & 6.3 & + \\
\hline 29.5 & 0.1 & 6.1 & 15 & 3.60 & 6.3 & + \\
\hline \multirow[t]{4}{*}{31.5} & 0.1 & $\mathrm{Nd}$ & $\mathrm{Nd}$ & $\mathrm{Nd}$ & $\mathrm{Nd}$ & $\mathrm{Nd}$ \\
\hline & 1 & 5.9 & 5 & 1.36 & 6.2 & + \\
\hline & 10 & 5.9 & 5 & 1.78 & 6.0 & + \\
\hline & 100 & 5.7 & $<5$ & 1.10 & 5.9 & + \\
\hline
\end{tabular}

CN: negative control; +: positive; -: negative; Nd: not done; $\mathrm{Al}_{2}\left(\mathrm{SO}_{4}\right)_{3}$ : aluminum sulfate; $\mathrm{PCR}$ : polymerase chain reaction; NTU: nephelometric turbidity units. 
TABLE 3 - PCR detection of Cryptosporidium in three samples of raw water from the Iguaçu, Iraí, Passaúna, and Rio Pequeno water treatment plants (Metropolitan Region of Curitiba, Paraná, Brazil) obtained between December 2008 and January 2009.

\begin{tabular}{|c|c|c|c|c|c|c|c|c|c|}
\hline \multirow[b]{3}{*}{ WTP } & \multicolumn{9}{|c|}{ Source of DNA template } \\
\hline & \multicolumn{3}{|c|}{$\begin{array}{l}\text { Decanted water } \\
\text { from Jartest assays }\end{array}$} & \multicolumn{3}{|c|}{$\begin{array}{l}\text { Flocculated material } \\
\text { from Jartest assays }\end{array}$} & \multicolumn{3}{|c|}{$\begin{array}{c}\text { Sludge } \\
\text { from WTP }\end{array}$} \\
\hline & $1^{\text {th }}$ & $2^{\text {nd }}$ & $3^{\text {rd }}$ & $1^{\text {th }}$ & $2^{\text {nd }}$ & $3^{\text {rd }}$ & $1^{\text {th }}$ & $2^{\text {nd }}$ & $3^{\text {rd }}$ \\
\hline Iguaçu & - & - & - & - & - & - & - & - & - \\
\hline Passaúna & + & - & - & - & + & - & - & + & - \\
\hline
\end{tabular}

+: positive; -: negative; WTP: water treatment plants; PCR: polymerase chain reaction; DNA: deoxyribonucleic acid.

No amplification of Cryptosporidium DNA was obtained with the XIAO primers; however, the AWA primers allowed detection of the parasite in two samples from four WTP catchment areas (Table 3). In Rio Pequeno, the PCR was positive in samples from sludge on the second and third collection. Flocculated material obtained from the water of the Passaúna catchment area was PCR-positive on the first day of collection, whereas the sludge samples from this WTP were PCR-positive on the second day of collection (Table 3).

\section{DISCUSSION}

The detection of pathogens and the safety of drinking water are topics of great concern to health authorities. Highly sensitive and rapid techniques are necessary to detect and mitigate environmental contamination by organisms such as Cryptosporidium. The PCR is an alternative specific and sensitive technique that has been tested in several studies worldwide ${ }^{20-23}$.

To adopt PCR for the detection of microorganisms in environmental samples, it is necessary to standardize procedures to obtain good quality DNA. In this study, we initially tested different techniques for the extraction of DNA from Cryptosporidium oocysts spiked in reagent water. All of the procedures were aimed at physically or enzymatically disrupting oocyst walls, as Cryptosporidium oocysts have 40-nm double membrane walls ${ }^{24}$ that make them resistant to breakage and DNA liberation. The subsequent purification of the DNA is also a critical step, as the sensitivity of the PCR technique can be affected by the presence of organic and inorganic substances, especially in water, feces, and soil ${ }^{21,22}$. According to our results, the purification conducted with the classical phenol-chloroform-isoamyl alcohol method is less efficient (a minimum of $10^{3}$ oocysts were required), most likely because of the loss of DNA during the deproteinization steps. The saltingout method resulted in an improvement in the limit of detection $\left(10^{2}\right.$ oocysts). However, the ChargeSwitch ${ }^{\circledR}$ kit yielded the best results with PCR and nested-PCR using the XIAO primers: five and two oocysts, respectively, could be detected. A previous report indicated that 10 oocysts could be detected in reagent water with nested-PCR using the same primers used in our study and templates obtained with the QIAquick Stool Mini Kit (QIAGEN Inc., Valencia, California, USA) ${ }^{25}$. The optimal performance achieved with the extraction kit in the present work can be attributed to the charged capture of the DNA in beads that improved the quality of the template. For this reason, the kit was chosen for DNA extraction in the subsequent experiments with spiked raw water.

Spiked raw water samples were subjected to coagulation/ flocculation with aluminum sulfate to concentrate the parasites, a method already reported to be useful for recovering oocysts from environmental raw water ${ }^{26}$. An additional purification of oocysts was accomplished by separation in a sucrose gradient to reduce PCR inhibitors. Unfortunately, even though the PCR and nested-PCR conducted with XIAO primers had the best analytical sensitivity of the previous tests, successful detectable amplification was not achieved when these methods were applied to the processed material from spiked water. Only the one-step PCR with the AWA primers was sensitive enough to detect Cryptosporidium in the samples. Because the same templates were used in the PCR with the XIAO and AWA primers, a possible explanation for this failure is that persisting PCR inhibitors were more detrimental in reactions with the first primers; indeed, the target fragments for the first set of primers were four to six times longer than those generated with the AWA primers. Future studies with nested-PCR should focus on the analysis of post-treated water where organic matter that could have an inhibitory effect on the PCR reaction is supposedly removed.

Even though the use of the AWA primers did not provide the best sensitivity of all reactions, PCR with these primers allowed the detection of 0.1 oocyst $/ \mathrm{mL}$ in the spiked samples of raw water, corresponding to a total of 200 oocysts in $2 \mathrm{~L}$ of processed water. All replicates were positive despite the variation in the concentration of the coagulant or in physicochemical parameters, indicating that slight variations in the amount of coagulant do not influence the results of the PCR.

After standardizing the methodology for the detection of Cryptosporidium in the raw water samples, a field survey was conducted to evaluate the presence of the protozoa in water catchments points from four WTPs in Curitiba, Parana, Brazil. 
One sample of raw water from the Passaúna WTP was positive according to PCR. The oocyst concentration was estimated to be equal to or greater than 0.1 oocyst $/ \mathrm{mL}$ or 100 oocysts $/ \mathrm{L}$, which was the limit of detection for the method standardization. This level of contamination is much higher than those observed in recent reports in Brazil, where the presence of 15-60 oocysts/L in $62.5 \%$ of samples from a river that supplies a WTP in Campinas, São Paulo ${ }^{27}$ and 0.15 oocysts/L in $26 \%$ of samples in a unique WTP in Maringá, Paraná ${ }^{28}$ was detected. Further investigations involving periodic samplings are needed to assess whether such a level of contamination in the Passaúna catchment point is typical.

In addition to testing the raw water using the standardized methodology, the sludge obtained at the WTPs was also processed by PCR to improve the chances of detecting the oocysts. One sample from Passaúna and two samples from Rio Pequeno were positive by PCR. The higher frequency of the parasites in the sludge than in the flocculated material may be related to the fact that a larger amount of sludge (1L) was processed. In addition, the sludge sample was produced from a large-scale coagulation process at the WTPs.

Even though the sludge was not tested in the spiking experiments, the successful detection of Cryptosporidium in sludge samples suggests that the method used to concentrate the oocysts from this material is suitable for further detection by PCR. Therefore, processing the sludge from a WTP could be an additional way of screening for Cryptosporidium in watersheds that supply urban areas.

Raw water and water sludge samples from catchments points from two out of four WTPs were contaminated with Cryptosporidium. These results reinforce the need to maintain a systematic monitoring of Cryptosporidium in drinking water and to protect the water catchment from potential sources of contamination such as human and animal waste from urban areas or livestock farms.

In Brazil, screening for Cryptosporidium in water is not compulsory, but it is recommended by Regulation 2914/2011 of the Ministry of Health ${ }^{11}$. The screening for Cryptosporidium and Giardia at water catchment points should be performed whenever the annual geometric average of Escherichia coli is higher than $10^{3} / 100 \mathrm{~mL}$. Furthermore, this regulation recommends that whenever Cryptosporidium is detected in surface water at concentrations equal to or greater than 3 oocysts/L, the final treated water obtained by rapid filtration must have a turbidity less than or equal to $0.3 \mathrm{NTU}$ in $95 \%$ of monthly samples.

Current techniques for the environmental detection of Cryptosporidium require the filtration of large volumes, elution, isolation, and enumeration of the oocysts by immunofluorescent microscopy ${ }^{10,29}$. However, this approach cannot determine whether Cryptosporidium oocysts are viable or whether they belong to a human-infective genotype. Molecular techniques have the potential to assess oocyst viability (RT-PCR), to quantify the amount of parasites (Real-Time PCR), and to obtain specific or genotypic identification (multiplex PCR and sequencing). Thus, molecular techniques are a promising methodology for monitoring Cryptosporidium in surface water and are likely to reduce the risks of human contamination and outbreaks similar to those that have occurred in developed countries.

\section{CONFLICT OF INTEREST}

The authors declare that there is no conflict of interest.

\section{FINANCIAL SUPPORT}

This work was supported by the Brazilian Health National Foundation (FUNASA) of the Brazilian Ministry of Health, Brazil.

\section{REFERENCES}

1. Smith HV, Rose JB. Waterborne cryptosporidiosis: current status. Parasitol Today 1998; 14:14-22.

2. Sterling CR, Arrowood MJ. Cryptosporidia. In: Kreier JP, editor. Parasitic Protozoa. Academic Press Inc; 1993. p. 191-192.

3. Smith HV, Cacciò SM, Tai A, Mclauchlin J, Thompson RCA. Tools for investigating the environmental transmission of Cryptosporidium and Giardia infections in humans. Trends Parasitol 2006; 22:161-167.

4. Medema GJ, Schijven JF. Modeling the sewage discharge and dispersion of Cryptosporidium and Giardia in surface water. Water Res 2001; 35:43074316.

5. Kuczynska E, Shelton D. Method for detection and enumeration of Cryptosporidium parvum oocysts in feces, manures, and soils. Appl Environ Microbiol 1999, 65:2820-2826.

6. Redlinger T, Corella-Barud V, Graham J, Galindo A, Avitia R, Cardenas V. Hyperendemic Cryptosporidium and Giardia in households lacking municipal sewer and water on the United States - Mexico border. Am J Trop Med Hyg 2002; 66:794-798.

7. Pereira JT, Costa AO, Oliveira-Silva MB, Scuchard W, Osaki SC, Castro EA, et al. Comparing the efficacy of chlorine, chlorine dioxide, and ozone in the inactivation of Cryptosporidium parvum in water, Parana-Brazil. Appl Biochem Biotech 2008; 151:464-473.

8. Robertson B, Sinclair MI, Forbes AB, Veitch M, Kirk M, Cunliffe D, et al. Case control studies of sporadic cryptosporidiosis in Melbourne and Adelaide, Australia. Epidemiol Infect 2002; 128:419-431.

9. Lemarchand K, Lebaron P. Occurrence of Salmonella spp. and Cryptosporidium spp. in a French coastal watershed: relationship with fecal indicators. FEMS Microbiol Lett 2003; 218:203-209.

10. United States Environmental Protection Agency. USEPA method 1623: Cryptosporidium and Giardia in water by filtration/IMS/FA. EPA 821R-01-025. Office of Water. Washington, DC: Environmental Protection Agency; 2001.

11. Ministério da Saúde. Portaria n. 2.914, de 12 de dezembro de 2011. Dispõe sobre os procedimentos de controle e de vigilância da qualidade da água para consumo humano e seu padrão de potabilidade. Diário Oficial da República Federativa do Brasil, 239; 2001. p. 39-46.

12. Silva MBO. Infecção natural e experimental de Cryptosporidium e caprinos: avaliação clínica, parasitológica e da resposta humoral. [PhD Thesis]. [Belo Horizonte]: Universidade Federal de Minas Gerais; 2000.

13. Sambrook J, Fritsch EF, Maniatis T. Molecular Cloning: A Laboratory Manual. New York: Cold Spring Harbor Laboratory Press; 1989.

14. Miller SA, Dykes DD, Polesky HF. A simple salting out procedure for extracting DNA from human nucleated cells. Nucleic Acids Res 1988; $16: 1215$. 
15. Awad-el-Kariem FJ, Warhurst DC, McDonald V. Detection and species identification of Cryptosporidium oocysts using a system based on PCR and endonuclease restriction. Parasitol 1994; 109:19-22.

16. Almeida TTC. Padronização e avaliação de métodos moleculares para detecção de oocistos de Cryptosporidium spp (Apicomplexa: Cryptosporidiidae) em amostras fecais: extração de DNA genômico e PCR (reação em cadeia pela polimerase). [PhDThesis]. [São Paulo]: Universidade de São Paulo; 2004.

17. Xiao L, Escalante L, Yang C, Sulaiman I, Escalante AA. Phylogenetic analysis of Cryptosporidium parasites based on the small-subunit rRNA gene locus. Appl Environ Microbiol 1999; 65:1578-1583.

18. Rubin AJ, Evers DP, Eyman CG, Jarrol EL. Inactivation of gerbil-cultured Giardia lamblia cysts by free chlorine. Appl Environ Microbiol 1989; 55:2592-2594.

19. Yanko WA. Occurrence of pathogen in distribution and marketing municipal sludges. County Sanitation Districts of Los Angeles County, Whittier, CA. In: EPA/625/R - 92/013. Environmental Regulations and Technology. Control of pathogens and vector attraction in sewage sludge; 1992.

20. Almeida A, Moreira MJ, Soares S, Delgado ML, Figueiredo J, Silva E, et al. Presence of Cryptosporidium spp. and Giardia duodenalis in Drinking Water Samples in the North of Portugal. Korean J Parasitol 2010; 48:43-48.

21. Ramirez NE, Sreevatsan S. Development of a sensitive detection system for Cryptosporidium in environmental samples. Vet Parasitol 2006; 136: 201-213.
22. Higgins JA, Jenkins MC, Shelton D, Fayer R, Karns JS. Rapid extraction of DNA from Escherichia coli and Cryptosporidium parvum for use in PCR. Appl Environ Microbiol 2001; 67:5321-5324.

23. Monis PT, Saint CP. Development of a Nested-PCR assay for the detection of Cryptospodium parvum in finished water. Water Res 2001; 35:16411648.

24. Harris JR, Petry F. Cryptosporidium parvum: structural components of the oocyst wall. J Parasitol 1999; 85:839-849.

25. Yu JR, Lee SU, Par WY. Comparative Sensitivity of PCR Primer Sets for Detection of Cryptosporidium parvum. Korean J Parasitol 2009; 47: 293-297.

26. Karanis P, Kimura A. Evaluation of three flocculation methods for the purification of Cryptosporidium parvum oocysts from water samples. Lett Appl Microbiol 2002; 34:444-449.

27. Cantusio Neto R, Santos LU, Sato MI, Franco RM. Cryptosporidium spp. and Giardia spp. in surface water supply of Campinas, southeast Brazil. Water Sci Technol 2010; 62:217-222.

28. Nishi L, Baesso ML, Santana RG, Fregadolli P, Falavigna DL, FalavignaGuilherme AL. Investigation of Cryptosporidium spp. and Giardia spp. in a public water-treatment system. Zoonoses Public Health 2009; 56:221-228.

29. Osaki SC, Costa AO, Troiano LDC, Kruger ER, Pereira JT, Fernandes NLM, et al. Production of anti-Cryptosporidium polyclonal antibodies and standardization of direct immunofluorescence for detecting oocysts in water. Rev Soc Bras Med Trop 2011; 44:587-590. 